46 ( 1 ) : 11 15, 1996

\title{
慢性非細菌性前立腺炎に対する経尿道バルーンレーザー 温熱療法の長期治療結果
}

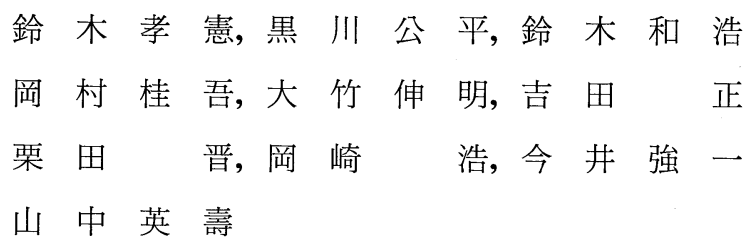

群馬大学医学部泌尿器科（主任：山中英壽教授）

(平成 7 年 9 月 8 日 受付)

要 旨： 2 年以上治療を受けている慢性非細菌性前立腺炎 5 症例に対し，経尿道バルーンレーザー温 熱療法 (TUBAL-H) を施行し, 治療効果について 1 年以上経過観察した。治療効果は主訴スコアー判 定では 3 力月後 5 例中消失 1 例, 軽快 4 例, 1 年後 3 例中軽快 2 例, 不変 1 例で, I-PSS スコアー判定で は 3 力月後軽快 4 例, 不変 1 例, 1 年後軽快 2 例, 不変 1 例であった. EPS 中の白血球数による効果判 定では, 3 力月後正常化 4 例, 改善 1 例, 6 力月後全例で正常化し 1 年間効果は継続した. TUBAL-H は難治性慢性非細菌性前立腺炎に有効な治療法の一つと考えられた。

Key words: TUBAL-H, 非細菌性前立腺炎, 温熱療法

(北関東医学 46 (1)：11 15，1996)

\section{はじめに}

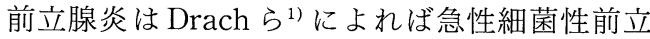
腺炎, 慢性細菌性前立腺炎, 非細菌性前立腺炎抢よ びプロスタトディニアに分類されている. 非細菌性 前立腺炎は診断が煩雑で，慢性化し難治性となる症 例をよく経験する。この難治性の慢性前立腺炎に対 する治療は種々試みられているが，治療抵抗性で， 新たな治療法が求められている.

最近, 慢性非細菌性前立腺炎に対する治療法とし て温熱療法2)が注目されている.今回, $\mathrm{Nd}$ ：YAG レーザーを使用した経尿道バルーンレーザー温熱療 法（TUBAL-H）を難治性の慢性非細菌性前立腺炎 症例に施行し,長期に経過観察が可能であったので, その治療効果，継続期間について報告する。

\section{対象と方法}

対象は 5 例(35-75歳, 平均60.2歳)で, 慢性前立腺炎 の診断で抗菌剤, 消炎鎮痛剂および前立腺マッサー
ジの治療を泌尿器科医師により少なくとも 2 年以上 (平均治療期間 2 年10力月) 受けていた症例であっ た. 1 例は 4 年前に前立腺肥大症の治療 (TURP) の既往があった。尿 $\left(\mathrm{VB}_{1}\right.$ または $\left.\mathrm{VB}_{3}\right)$ 細菌培養, 前立腺圧出液（EPS）の細菌培養は全例陰性で，ク ラミジア抗原も陰性であった.

治療方法：TUBAL-H についてはすでに報告し たが3), 以下に簡単に述べる. 腰椎麻酔下に, バルー ンレーザープローブを前立腺部尿道に留置し, バ ルーン内を $10^{\circ} \mathrm{C}$ の冷水を循環させ尿道を冷却する. 会陰部より熱電対を前立腺組織内に扦入し，治療温 度設定用に使用した。前立腺組織内最高温度を $43^{\circ} \mathrm{C}$

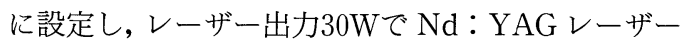
を照射し前立腺を加温した。治療時間は初期の 3 例 は20分間， 2 例は 30 分間であった。治療中の前立腺

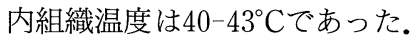

治療効果判定：症状は前立腺肥大症で使用されて いる I-PSS ${ }^{4}$ スコアー, 来院時の主訴スコアー ( 5 点 満点 $)^{3)}$ および 2 つを合わせた総自覚症スコアーを

論文別刷請求先 $\overline{\mathbf{T}} 371$ 前橋市昭和町三丁目39-22 群馬大学医学部泌尿器科学教室 
治療前後で判定した. EPS 中の白血球数を細菌性前 立腺炎に抢ける薬効評価基準 5 に従い grade $0 ; 0$ - 4 個/hpf, grade $1 ; 5-9$ 個/hpf, grade $2 ; 10-29$ 個/hpf, grade $3 ; 30$ 個/hpf から視野の1/2末満, grade 4 ; 白血球が視野の $1 / 2$ 以上の面積を占めるに 分類し, 治療前後で白血球数の変化を観察した. 前 立腺重量を経直腸超音波断層法で測定し, 重量 $(\pi)$ 6・abc）の変化を観察した。また，細菌性前立腺炎 における薬効評価基準 ${ }^{5}$ に従い, 自覚症状に対する 効果, EPS 中の白血球に対する効果について判定し た.

\section{結果}

治療後長期に経過観察が可能であったのは 4 例 で, 1 例は治療後 5 力月後に肺気腫により他院に入 院したため, 長期効果判定より除外した。

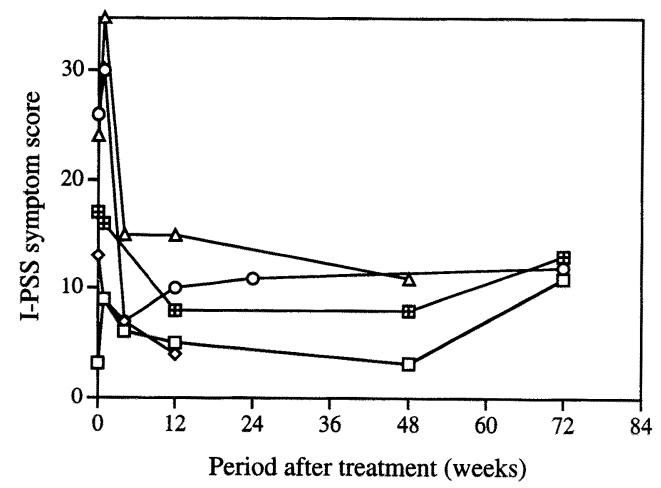

Fig. 1. Changes of I-PSS symptom score after TUBAL-H.

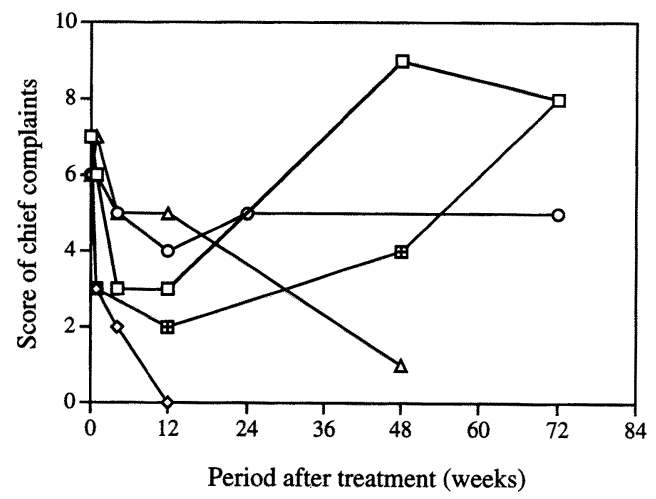

Fig. 2. Changes of score of chief complaints after TUBAL-H.

\section{1. 自覚症状の改善について}

I-PSS による自覚症状の変化は, 治療前スコアー3 -26 (平均16.6) で， 3 力月後 4-15 (平均8.4), 1 年後 3-11 (平均7.3), 1 年半後11-13 (平均12) で あった(図 1 )。薬効評価基準による効果判定は 3 力 月後 5 例中軽快 4 例, 不変 1 例, 1 年後 3 例中軽快 2 例, 不変 1 例, 1 年半後 3 例中軽快 2 例, 不変 1 例 であった。主訴スコアーでは, 各症例は 2 つの主訴 で来院し, 治療前総主訴スコアーは 6-7 (平均 6.4) であった. 3 力月後 $0-5$ (平均 2.8), 1 年後 1-9 (平均 4.7), 1 年半後 5-8 (平均 7 ) (図 2) で, 効果判定では 3 力月後 5 例中消失 1 例, 軽快 4 例, 1 年後 3 例中軽快 2 例, 不変 1 例, 1 年半後 3 例中軽 快 1 例, 不変 2 例であった. I-PSS と自覚症状をあわ せた総自覚症状スコアーは治療前10-32(平均22.6), 3 力月後 $4-20$ (平均 11.2 ), 1 年後 12 (平均 12 ), 1

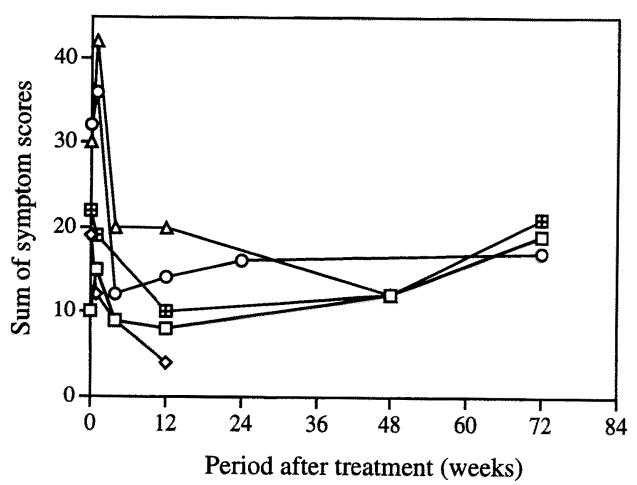

Fig. 3. Changes of sum of symptom scores after TUBAL-H.

年半後17-21 (平均19) であった（図 3 ). 効果判定 では 3 力月後 5 例中すべて軽快, 1 年後 3 例中軽快 2 例, 不変 1 例, 1 年半後 3 例中軽快 2 例, 不変 1 例であった. 主訴よりみた自覚症状の改善は約 1 年 間継続し, 1 年半後では症状の再燃傾向が観察され た. I-PSS と総自覚症状では症状の改善は 1 年より 1 年半継続した. 前回報告 ${ }^{3}$ したように,すべての症 例で内服による治療は行わず 1 年間経過観察が可能 であった。

\section{2. 他覚所見の改善について}

\section{1) EPS 中の白血球変化について}

治療前白血球数 grade 2 が 3 例, grade 3 が 2 例で あった. 治療後 3 力月後には 4 例が grade 0,6 力月 


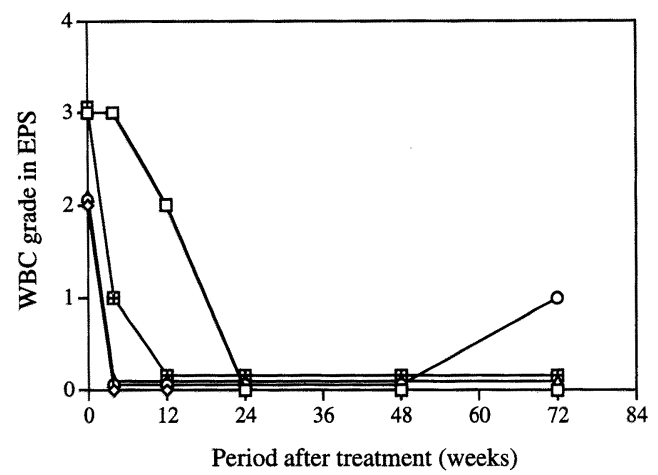

Fig. 4. Changes of white blood cell (WBC) grade in expressed prostatic secretion (EPS) after TUBAL-H.

後にはすべての症例で白血球数は grade 0 となり, 効果判定では EPS 中の白血球数は正常化し, その効 果は 1 年間継続した. 1 年半後に 1 例に EPS 中の白 血球数 grade 1 の再出現がみられた (図 4 ). バルー ンレーザー温熱療法の効果は EPS 中の白血球数で 判断すると 1 年以上継続することが予想された。

\section{2 ) 前立腺重量の変化について}

1 年以上観察できた 3 例について検討した． 1 例 は治療前の前立腺重量は $31.3 \mathrm{ml}$ で, 1 年半後 23.7 $\mathrm{ml}$ と縮小傾向が見られたが, 他の 2 例は治療前と長 期での重量の変化は見られなかった(図 5 ). 温熱療 法による前立腺重量変化は少ないものと考えられ た.

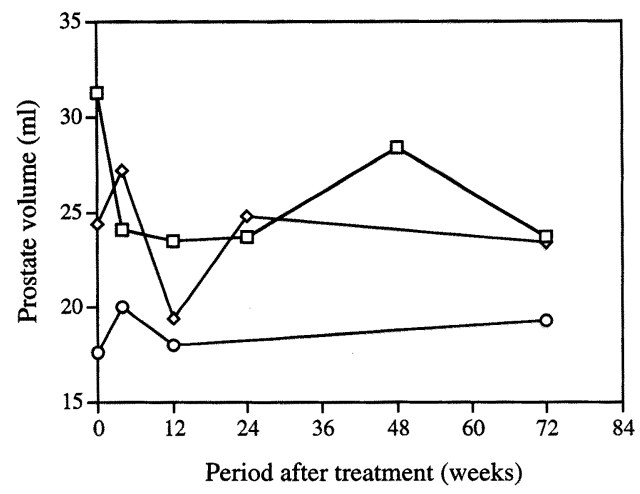

Fig. 5. Changes of the prostate volume after TUBAL-H.
考察

慢性非細菌性前立腺炎には難治症例が見られ， 種々の治療にも抵抗性で新たな治療法が検討されて 认る. 今回, 難治性の慢性非細菌性前立腺炎 5 症例 に TUBAL-H を施行し, 良好な自覚症状の改善が 得られた。その治療効果継続期間は 1 年以上と考元 られた.炎症所見の変化を EPS 中の白血球数で観察 しても, 治療効果は良好で, 効果の継続は 1 年以上 と考えられた。

前立腺炎に対する温熱療法はマイクロ波 ${ }^{2,6 \sim 8)}$, パ ルス超音波9), レーザー3)が使用され, 治療経路とし ては経直腸 $2,7 \sim 9)$ または経尿道 ${ }^{3,6)}$ 操作がとられてい る.治療効果は判定基準が異なるが，やや有効以上 の反応は $50-87 \%$ に見られている ${ }^{2,6 \sim 9)}$. 今回の症例で は主訴スコアーによる判定では， 3 力月後軽快以上 は 5 例中 4 例に見られ， 1 年後では軽快は 3 例中 2 例に認められた。難治性の症例に対する治療効果と しては十分であると考えられた. 症例数が 5 例と少 ないこと, プラセボ効果や前立腺マッサージの治療 効果が加味されている可能性が考えられるが，2 年 以上治療を受けていた症例であったことより難治性 の慢性非細菌性前立腺炎に対する TUBAL-H は有 効な治療方法の一つと考えられた。

慢性前立腺炎に対する温熱療法の作用機序につい ては不明な点が多い. 前立腺組織内温度 $43^{\circ} \mathrm{C}$ 以下で は壊死などの組織学的変化は少ないと考えられ $3^{10)}$. 前立腺の縮小効果については, 今回の症例では 1 例に前立腺重量は 1 年半後にやや減少したが, 他 の 2 例では治療前後で大きさに変化は見られなかっ た. Baert ら ${ }^{6)}$ も治療前後における前立腺重量に変 化は見られなかったと報告している．温熱療法によ る前立腺縮小効果は少ないものと考えられた。 $\alpha$ レ セプターや平滑筋組織に対する作用, 前立腺組織内 の血流改善にともなう代謝の賦活化が考えられてい $ろ^{7)}$. Servadio $ら^{2)}$ は温熱療法の前後で前立腺針生 検を施行し, 治療後組織学的に炎症所見が消失した 例を報告している.EPS 中の白血球数変化が見られ ないとの報告8,9) もあるが, 今回の症例, 公文ら ${ }^{7)}$ の 報告では EPS 中の白血球数は減少し, 炎症所見の消 失が温熱燎法の治燎効果の一つと考えられた。

最後に, 今回の治療時間は20分または30分間で 行ったが, 最も良い治療時間の設定が必要である. また, 外来で治療を行う場合, 経尿道的操作は比較 
的神経質な患者が多いため, 治療が受け入れやすい ように工夫することが大切であると考えられた。

\section{結語}

難治性慢性非細菌性前立腺炎 5 症例に対し, TUBAL-H を施行し, 良好な治療成績が得られた。 また，治療効果は 1 年以上継続することが予想され た. TUBAL-H は難治性慢性前立腺炎症例に試みて 良い治療法であると考えられた。

\section{文献}

1) Drach GW, Fair WR, Mearces EM : Classification of benign diseases associated with prostatic pain: prostatitis or prostatodynia? J Urol $120: 266,1978$.

2) Servadio C, Leib $Z$ : Chronic abacterial prostatitis and hyperthermia. A possible new treatment? Br J Urol 67 : 308-311, 1991.

3) Suzuki T, Kurokawa K, Suzuki Kz, et al : Transurethral balloon laser hyperthermia for chronic non-bacterial prostatitis: A clinical trial. Int J Urol 2 : 29-32, 1995.

4) Cockett AT, Aso Y, Denis L, et al: Recommendations of the international consensus comittee. The international consulta- tion on benign prostatic hyperplasia (BPH)

(Proceedings), Paris, WHO, 1991, pp289340.

5）前立腺炎診療マニュアル。前立腺炎シンポジウ 厶組織委員会, (財) 前立腺研究財団 (編), 東 京, 金原出版, 1990, pp158-164.

6) Baert L, Willemen P, Ameye F, et al: Transurethral microwave hyperthermia: An alternative treatment for prostadynia? Prostate 19 : 113-119, 1991.

7）公文裕巳，小野憲昭，宇埜 智ら：慢性前立 腺炎に対する経直腸的温熱療法の臨床的検討. 日泌尿会誌 $84 ： 265-271 ， 1993$.

8）目黒則男, 近藤宣幸, 清原久和：慢性非細菌 性前立腺炎に対する経直腸温熱療法の臨床成 績. 泌尿紀要 39：1153-1156，1993.

9）西村泰司, 堀内和孝, 沖 守ら：難治性非 細菌性前立腺炎およびプロスタトディニアに対 する経直腸的超音波治療。泌尿紀要 39 ：907911, 1993.

10) Suzuki T, Kurokawa $K$, Suzuki $K z$, et al : Thermal damage of normal and hyperplastic prostates to transurethral balloon laser therapy in dogs. Int J Urol 1 : 162-166, 1994. 


\title{
TRANSURETHRAL BALLOON LASER HYPERTHERMIA FOR CHRONIC NON-BACTERIAL PROSTATITIS : LONG-TERM FOLLOW-UP RESULTS
}

\section{TAKANORI SUZUKI, KOHEI KUROKAWA, KAZUHIRO SUZUKI, KEIGO OKAMURA, NOBUAKI OHTAKE, TADASHI YOSHIDA, SUSUMU KURITA, HIROSHI OKAZAKI, KYOICHI IMAI, HIDETOSHI YAMANAKA}

\author{
Department of Urology, Gunma University School of Medicine, \\ Maebashi, Gunma 371, Japan \\ (Director: Prof. Hidetoshi Yamanaka)
}

\begin{abstract}
Five patients with chronic non-bacterial prostatitis, which was resistant to conventional treatments, underwent transurethral balloon laser hyperthermia (TUBAL-H), and were followed for more than one year. In regard to the chief complaints, the symptoms were resolved in 1 patient and improved in 4 at three months after treatment, and improved in 2 and persisted in 1 at one year after treatment. According to I-PSS scores, the symptoms were improved in 4 patients and persisted in 1 at three months, and improved in 2 and persisted in 1 at one year. White blood cells in expressed prostatic secretions were absent in 4 patients and decreased in 1 at three months, and absent in all cases between six months and one year. TUBAL-H was thought to be useful for treating chronic non-bacterial prostatitis.
\end{abstract}

Key words: TUBAL-H, Non-bacterial prostatitis, Hyperthermia 